\title{
Firms Strategies on E-payments Market: From Breaks to Convergence?
}

\author{
Antoine Gentier \\ Correspondence: Antoine Gentier, CERGAM FEG Aix Marseille University France, France. E-mail: \\ antoine.gentier@univ-amu.fr
}

Received: May 25, 2012

Accepted: June 7, 2012

Online Published: December 31, 2012

doi:10.5539/ibr.v6n2p43

URL: http://dx.doi.org/10.5539/ibr.v6n2p43

\begin{abstract}
Payment means have evolved since the development of the E-trade. E-trade has abolished physical frontiers and entrepreneurs can meet a foreign demand even for small exchange. E-trade allows exchange between people that could not have met before the Internet. A bookseller in the US can now send his products easily in Europe and more the product is digitalized, easier and costless the exchange can be done. These new opportunities had demanded new means of payment. The traditional monetary systems are designed mainly on geographical grounds and they generate very high transaction costs on international level. E-trade demands international micropayment systems that are cost competitive. The paper explains the emergence of E-payment systems and tries to give a taxonomy regarding to their strategies. Firms such as PayPal first dominated the international micropayment markets, but the traditional banks are now entering this market. At the same time, PayPal is trying to enter the traditional market of current accounts. The emergence of mobile phone payments has brought new actors in the market. All these changes combined with a strict regulation framework lead to more cooperation and convergence than breaking strategies.
\end{abstract}

Keywords: E-payments, innovation

JEL codes: G21, E31, E42

\section{Introduction}

The emergence of E-payment is an innovation from the traditional model of payment. The traditional model of payment has emerged in 1971. This model is characterized by a hierarchical production of money controlled by a central bank. The money issued by the central bank has legal tender over a geographical territory. This money is the monetary base for the commercial banks' clearing. The money users have no choice and face very high costs when they want to buy something in a foreign currency abroad. The transaction costs are high for two main reasons: first the oligopoly position of banks allows them to charge high fees and the system has a lot of intermediaries. Second the exchange rate volatility is also a problem, it sometimes compels currency users to buy insurance schemes to protect themselves. Moreover, inflation is linked to traditional currencies. For instance prices in France between 1970 and 2009 have increased by $600 \%$, we just remind the reader that without monetary creation and with the same productivity gains, prices should have felt. This brief state of art of the "quality" of traditional currencies shows the opportunities to create better or more efficient payment systems. Money has traditionally three functions: unit of account, general medium of exchange and store of value. Inflation, transaction costs and exchange rate volatility of the traditional payment systems give plenty room to innovate in order to reduce the costs for consumers.

Among numerous electronic payment systems, there are E-Gold and PayPal. These two systems offer solutions to some problems created by traditional currencies. PayPal and E-Gold have very different strategies.

E-Gold proposes a system based on a virtual exchange of property rights upon a stock of gold (silver, platinum and palladium are also available). The bank keeps a $100 \%$ reserve of gold in its virtual vaults, and charges some fees on deposits and on transactions. This model is not as exotic as it could appear at the first glance. This model was very common during the $18^{\text {th }}$ century for deposit banking. In the $18^{\text {th }}$ century, banks had a $100 \%$ reserve and the accountancy was based on the weight of gold. The deposit was made in a quantity of gold or silver (grams), and all transactions were measured with the weight of gold. All the contracts between the bank and its depositors were denominated in grams of gold, in order to escape to the already frequent money manipulations on coins from governments or kings. E-Gold offers a protection against inflation and the monetary creation from the central 
banks. The rising price of gold since 1970 gives a good indication of the consequence of monetary creation. As a matter of fact, it is not gold that have seen its value increased, it is more the dollar and all other currencies that have been devaluated by a strong pace of monetary creation. E-Gold proposal is characterized by the will to build an independent system from the traditional currencies. Its strategy is a rupture from the traditional systems.

PayPal, on the other side uses traditional means of payments (credit cards) to transfer funds. The fees taken by PayPal are very competitive toward those demanded by the traditional actors, especially for international micropayments. PayPal allows transactions that could not have taken place in the traditional system (the standard fee for a check payment between the Euro zone and the US is about 28 Euros, so micro transactions on the internet would be discouraged). These two systems, based on different strategies have something in common: PayPal and E-Gold offer a competitive solution to the traditional payment systems.

The paper will analyze three main points: first the reasons of emergence for new payment systems will be developed, then we will propose a typology of different payment systems regarding to their strategies and at the end we will focus on the convergence or divergence between traditional actors and new ones on the electronic payment market.

\section{The Reasons of Emergence of New Electronic Payment Systems}

In order to convince money users to adopt new electronic means of payment, firms can propose several improvements from traditional currencies. Improvements can take place on the ability of money to keep its purchasing power in time and space, its liquidity or acceptability and the reduction of transaction costs. The emergence of E-trade has boosted the needs of international means of payments secure and cheap, even for micro transactions. Traditional currencies produced by central banks on a specific territory do not fit well with E-trade needs. E-trade has nearly abolished geographical frontiers and gives opportunities to buy products and services abroad.

If E-trade is the main reason of emergence of E-payments, there are also opportunities to innovate in order to improve the ability to keep the purchasing power of money in time and space.

\subsection{Inflation Performance Can Be Improved from Traditional Currencies}

There is no room here to make a historical review of prices inflation phenomena. We just focus on one illustration (the French case) to show that inflation performance of traditional currencies could be improved. All OECD countries have endured more or less the same phenomena. Official data from INSEE (French official institute for statistics) show the lost of the purchasing power of money. A 1970 French franc is equivalent to 0.99281 euro of the 2008 year (Note 1). It means that the purchasing power of money has been divided by 6.5 in forty years. Actually, inflation has been higher because monetary creation has been hidden by the productivity gains. With a stable amount of money in circulation, if there are productivity gains, the prices must go down. Growth has a deflationist effect, when there is no monetary creation. Inflation measures in developed countries are biased by the positive supply shock from India, China and other fast developing countries in South Asia. Nevertheless, OECD countries enjoyed a better situation than other countries (Zimbabwe...) but there is a room for more sound money. The seek for sound money is one of the main reason of the emergence of electronic payment systems based on an external and "real" guarantee such as gold, silver, platinum or palladium.

\section{2 "Dirty Floating" and the Volatility of Exchange Rates}

Volatility of exchange rates is mainly due to autonomous monetary policies between Japan, Europe and North America. The point is not to open again the debate between fixed and floating exchange rates, but to underline the fact that floating exchange rates induce some additional transaction costs for money users. They have to protect themselves against the fluctuations of the exchange rates. Money users could seek more sound money to stipulate their contracts. For reminding, the Euro/ Dollar exchange rate has moved between 1 EUR $=0.8$ USD and $1 \mathrm{EUR}=1.6 \mathrm{USD}$ since the creation of Euro (Note 2). The shift of value between currencies is an obstacle to international trade, and all the means to cover the risk are costly. Escaping from the volatility of exchange rates can be a strong motivation to enter into a system such as E-Gold.

\subsection{Traditional Currencies Are Unsuited to International Micropayments}

E-trade payments must satisfy the same needs than payment in a retail store. The main problem is to guarantee the transactions at a competitive cost for sellers and buyers. The costs are direct or indirect. Direct costs can be represented by transfer fees or for the seller by the implementation of a system of payment. But there are also some indirect costs. If the system has too boundaries, or is too complex to use, potential consumers won't adopt it. So innovations in the system of payment have several dimensions: easiness to use, competitive advantage on transaction costs, security and the quality of the system answer to the unsatisfied needs of consumers. 
Regarding to international E-trade, traditional currencies produced by central banks are very unsuitable. This hierarchical organization multiplies intermediaries between sellers and buyers ( 2 banks, 2 central banks, and a system to exchange the currencies). To sum up the problem and to give an order of height of the fees, to send $30 \$$ to a US current account from a current account in the Euro zone, this system can generate till $45 €$ of fees. In these conditions, international micropayments are discouraged, and E-trade transactions will not take place.

This gap allows an innovation on reducing the cost of the fees. From the sellers point of view there is also a room for innovation on the costs for online trade. The payment system is one of the most costly elements in the implementation of an online store, especially for small sellers with small turnover. One major reason to adopt PayPal by sellers is that it offers a guaranteed payment without the prohibitive costs from traditional banks.

\subsection{Synthesis}

Table 1 synthesizes the reasons of emergence of E-moneys. The main reason is electronic money systems are more suitable to the needs of E-trade, in order to guarantee a safe transaction at competitive cost. The costs are not only the fees charged for the transaction. It is also the time and the certainty of being paid (for the seller) and delivered (for the buyer). For instance, even if a check payment was price competitive to buy a book in the US for Europeans, it would take at least 3 weeks to be credited on the seller's bank account. This very long time delivery is a real obstacle to do E-trade, so people prefer to use some more convenient means of payment.

Table 1. Weaknesses of traditional currencies

\begin{tabular}{ll}
\hline \multicolumn{2}{l}{ Traditional currencies have several weaknesses that let some opportunities to innovate } \\
\hline General weaknesses & Weaknesses specific to E-trade \\
\hline 1. Inflation & 1. Security and trust for transactions without a direct contact between seller and buyer \\
2. Exchange rates volatility & 2. E-trade overtake territory limits of the currency \\
\begin{tabular}{ll} 
3. High international transaction costs & 3. High fees for micropayment \\
4. Limited convertibility & \\
\hline
\end{tabular}
\end{tabular}

\section{A Typology of Electronic Payment Systems Regarding to Their Strategies}

E-money systems tend to exploit the weaknesses of traditional currencies to offer to their customers more effective solutions on practical grounds at a competitive cost. E-money systems do not exploit all the weaknesses listed before, but they focus to one specific aspect to develop a competitive advantage. This specificity will allow presenting a typology of electronic payment systems regarding to their strategic choices. Three main different strategies can be observed on the market. First there are strategies based on diminishing the number of intermediaries to reduce the costs born by contractors. Second there are breaking strategies from traditional currencies. These strategies aim at creating a "monetary club" which is inflation proof from the monetary creation of the traditional systems. These monetary clubs can be divided in two kinds: there are clubs with an external guarantee of the electronic money (gold) and other with no external guarantee.

\subsection{Kill the Middleman Strategy: Reducing the Number of Intermediaries in Order to Diminish the Costs}

This strategy aims at economizing on the fees taken by intermediaries. In the traditional international payment scheme, the intermediaries are the banks (for the seller and the buyer) and all the bureaucratic costs generated by the clearing mechanism between two central banks currencies. It is not a breaking strategy for the traditional system. It's an improvement made on the credit card network. PayPal makes the classical illustration for this strategy. The success of PayPal is due to its ability to put seller and buyer in a direct relation. First Paypal is cost competitive (especially for micropayment) because there is less intermediaries to remunerate. Then, the payment organization is also more effective and less time consuming. The money transfer takes less time (72 hours) because there is less bureaucracy, and there is a guarantee of payment for the seller. The 72 hours payment time allows Paypal to check the liquidity of the buyer and so the risk of fraud is diminished compared to a check payment.

\subsection{The $18^{\text {th }}$ Century E-deposit Bank: Breaking Strategy from Traditional Currencies by Offering an Electronic Commodity Based Money}

The purchasing power of traditional currencies is diminished by monetary creation. This situation has urged entrepreneurs to create some electronic monetary clubs with an external guarantee of the value of the money. There are differences between these monetary clubs. Some such as E-Gold are completely isolated from traditional currencies and there is no convertibility with other currencies. Other such as GoldMoney offers gold 
convertibility with other currencies. E-Gold model is interesting. It represents a kind of revival of the deposit bank from the $18^{\text {th }}$ century. During the $18^{\text {th }}$ century, banking activities were separated and not merged inside banks. Money services (deposit banking) were split from investment banking specialized in credit activities. Deposit banks used to cover the deposits by $100 \%$ reserve in gold and they charged fees to keep the gold in their vaults and when the customers wanted to transfer it. The contracts were stipulated in weight of gold, in order to escape the money manipulations from governments.

E-Gold system allows the virtualization of cash payments. The payment is immediate and irreversible, like using cash. E-Gold commodity based system is designed to escape from inflation. The only difference with the $18^{\text {th }}$ century model relies on the legal tender of gold. Gold has no longer legal tender, and it is no more a universal means for repaying debt. During the $18^{\text {th }}$ century you could pay your debt and your taxes with gold, kings and governments used to accept it. Nowadays princes refuse to be paid in gold, and demand the use of fiat currencies. Fiat currencies allow them to extract tax inflation easily, and to obtain huge gains from seignoriage activities. The fiat currencies allow also financing public debt by reducing the value of the debt on the long run (inflation reduces the value of money and it is a transfer from creditors to debtors).

Table 2. Main features of the E-Gold system

- E-Gold organizes the property rights exchange on a quantity of metal.

- The depositor opens an account by buying a quantity of metal (gold, silver, platinum, palladium).

- The bank guarantees the transactions between customers. The bank charges fees for keeping the virtual commodity and on the transfers.

- There is no credit, the current accounts are all covered with $100 \%$ reserves of metal.

- The payment is immediate, there is no risk of default, customer account is always credited, and it's equivalent for the seller to be paid in cash.

- Customers can increase the amount of the commodity on their current account with two means: first by buying some other virtual units, or by selling products or services to customers that want to pay them with the virtual commodity.

- The system works on a voluntary base. Buyers and sellers choose to use this means of payment freely.

- For some aspects, this money can be seen as an alternative to the money produced by central banks.

\subsection{The E-money Club: Breaking Strategy from Traditional Currencies by Offering an Electronic Symbol for Monetary Transaction}

There are examples of money emergence in monetary history. Usually, a commodity acquires during a long time process the money statute. This commodity is selected by the market for its qualities of liquidity, acceptability and ability to store the purchasing power over time and space. Several commodities have acquired the money statute: cattle, seashells or metal (See Menger, 1981 and 1892; Mises, 1981; Davies, 2002). Since 1914, the reference to gold was abandoned de facto, and de jure since 1976 with the Kingston's agreements. Individuals are compelled to use money with no reference to an external commodity for merely a century. The money circulation is guaranteed by the legal tender of fiat money currencies and several regulations to demonetize gold (Note 3). Fiat money currencies had become the norm for money and some entrepreneurs want to set up money only backed by trust and voluntary agreement. A monetary club without an external commodity to guarantee the value of money is very seducing from an intellectual point of view. The Ripple project is one example, and proposes to make exchanges with a monetary symbol. There would be a cost advantage toward the E-deposit bank, because there is no cost for keeping the virtual gold. Nevertheless these projects do not work mainly because their money faced a problem of acceptability. Maybe there is no demand for a fiat money currency without legal tender. There are also illustrations of monetary clubs with small community trying to set up parallel currencies (Local Exchange Trading,) that can be mentioned. These experiences are intellectually stimulating but they have not succeeded to create a general medium of exchange.

\subsection{A Typology Proposal for E-payment System}

These three models (Kill the Middleman, E-Deposit Bank and E-Money Club) have been used to settle a typology of payment systems. The main strategic leverage is based on costs domination. Nevertheless the ergonomics plays also a key role. The design of the system has to be simple to use and safe for transaction. We have listed up several systems in table 3 . 
Table 3. Typology of several E-payment systems regarding to their strategies

\begin{tabular}{llll}
\hline Model & "Kill the Middleman" & $\mathbf{1 8}^{\text {th }}$ Century E-Deposit Bank & E-Money Club \\
\hline Strategy & Use the existing credit cards network to & Break from traditional system: & Break from traditional system: \\
& $\begin{array}{l}\text { offer cost effective services by reducing } \\
\text { the number of intermediaries }\end{array}$ & $\begin{array}{l}\text { Transactions are done by exchange of } \\
\text { property rights on a reference commodity }\end{array}$ & $\begin{array}{l}\text { Transactions are done by exchange of } \\
\text { property rights on a reference symbol }\end{array}$ \\
\hline Leverages & Cost domination & Cost domination & Cost domination \\
& Easiness to use & Inflation proof (or limited to the & \\
& Cost effective implementation for the & availability of the reference commodity) & \\
& seller & Virtualization of cash payment & Ripple monetary system (project) \\
Several & PayPal & E-Gold & \\
examples & ECache & c-gold & \\
& Eagle Cash & Crowne Gold & \\
& PayMate & e-dinar & \\
& Digicash & GoldExchange & \\
& & GoldMoney & \\
& & Liberty Reserve & \\
& Pecunix & \\
& SupraGold & \\
\end{tabular}

\section{Breaks or Convergence? Some Perspectives on the E-payment Market}

\subsection{General Remarks on E-payment Perspectives: Regulation Framework and Other Limits}

The firms' strategies on E-payment market are bound by regulatory framework that compels them to adopt specific statute. Regulation is a very strong factor for standardization and there is less room for breaking strategies. On the other side there are technical and economic limits.

\subsubsection{Regulation Plays a Key Role for Development of E-Payment and Pushes to Convergence}

\subsubsection{Legal Statutes Standardization}

Regulation framework has pushed firms to adopt in Europe the same statute than the traditional actors. Money creation is strictly regulated, and only banks are allowed to create money. Monetary authorities have immediately considered electronic forms of money as money by itself and all the regulation designed for bank money was applied to them. That's why the European branch of PayPal was compelled to be under the legal statutes of a bank. PayPal in Europe is a Luxembourgian bank. PayPal is not a real bank money creator, but as said before, the 72 hours payment time needed to guarantee the payment in the PayPal process creates money. In fact, each transaction made by PayPal, there is a monetary creation and 72 hours later there is a monetary destruction. The European banking regulation is very strict on this point (more than the US one) and only banks can create money, so PayPal must to be a bank to run its activities. Regulation framework is a factor of convergence between traditional actors and new incomers especially in Europe.

\subsubsection{Legal Tender Limit and the Question of Paying Taxes}

Electronic moneys offered by E-Money clubs have no legal tender disposition. Traditional currencies have this decisive advantage linked to the monopoly of money issued by central banks. An E-Gold certificate owner cannot pay his taxes with E-Gold. He must change them against a traditional currency so the benefits to use the E-money are limited. Moreover, some of these systems are in conflict with tax authorities on the question of hidden work. There are also problems to recover payroll taxes and value added taxes. Beyond the question of tax fraud, the main limit is the convenience of the E-Money to pay taxes or to repay debt. The question of credit and debt is one major limit to the use of E-Money that we will analyze beside. The legal tender question compels E-payment firms to develop some cooperative links with traditional actors and thus reduces the opportunity of a radical breaking strategy.

\subsubsection{Two Limits for E-payment Systems: Technical and Economic}

\subsubsection{Technical Limits}

The access to E-payment systems is limited by the needs to have a computer connected to the Internet and a credit card. There is a selection bias for the users of E-trade but the generalization of personal computer and the rapid development of networks (GSM, cable, DSL, WIFI...) put these services at the disposal of a large part of 
the population. It is not the core of the discussion but the technical limits are no longer a major obstacle. The development of mobile phone payments is very successful among developing countries (Kenya for instance). Mobile phones are a commodity diffused at a very large scale even in the poorest countries, prepaid credit cards have a very strong development, and so the techniques may soon offer E-payments facilities for nearly everybody. It's true that the generalization of E-payment can be crippled by technical or safety questions but the other limits give more durable barriers. Any E-payment system involves a network of actors to be implemented so it creates cooperation opportunities for the technical side and the marketing side. It's costless to sell a common brand to consumers with an association of banks, merchants and mobile phone providers. The complexity of these market pushes to some convergence and cooperation. Nevertheless competition process among the different E-payment systems is still very dynamic.

\subsubsection{Credit System Is Not Developed Inside the E-payment System}

E-Money clubs only offers payment services, and there is no credit service provided with their money. If you need a credit you must borrow in a traditional currency. In fact, we can imagine that inside the framework given by E-Gold or other issuer some credit banks appears to make loans stipulated in E-Gold. The sound monetary system could be an asset to create a credit system based on real saving in spite of monetary creation (deposits make loans instead of loans make deposit (Note 4)). Hayek (1975 and 1978) analyzed this situation from the theoretical point of view. Anyway the lack of credit opportunities in these systems is one of the major limits to its adoption by customers. It would be a regression to renounce to the credit that allows people to enjoy immediately durable goods. It is not the goal of the paper, but credit has a crucial role in economy on the demand side, it helps people to afford housing and durable goods (cars for instance) but on the supply side it gives the entrepreneurs the means to invest and to anticipate the liquidities generate by investment. An economy with no credit is less dynamic, because investment is limited to the equity capital owned by the entrepreneurs.

\subsection{Traditional Actors Are Now Very Concerned with E-payment and E-payment Actors Starts to Compete on Traditional Banks Market}

\subsubsection{Reactions from Traditional Actors: The Paymate Case}

A consortium of banks founded PayMate. Marginal at the end of the 1990s, the E-payment market is now mature and the development of the Internet on mobile phone has multiplied the opportunities. E-trade is going on Smartphone and the frontiers between E-trade, traditional trade and the payment systems frontiers are vanishing. Smartphones' applications allow a customer to do shopping in a retail store, to compare prices of the store with other retail or online stores and to pay online or in the retail store. The PayMate system is based on mobile phone. The company offers services to two kinds of customers. First consumers can use it to access to the promise of "Instant Payments Anytime, Anywhere". The services are also designed to business customers with four distinct markets: banks, mobile phone operators, merchants and technology service providers. The E-payment market evolution shows that banks do not master the entire process of payment. They must cooperate with other actors such as mobile phone companies for the technical side and merchants for the trade side to make their system workable.

Launched in 2007, PayMate offers a service based on what consumers have already: a credit card, a mobile phone and it works with any operator and any mobile phone. There is no additional equipment cost for the consumers. It's very cost effective and very popular in countries such as India because it does not need a 3G connection to work (it can also work with $3 \mathrm{G}$ ). The system is designed to work with SMS. There is no fee for consumers, the only limit is having an account with one of participating banks. Fees paid by the merchants at each transaction remunerate the system. It's the same old model as Visa and MasterCard: in exchange of the guarantee of being paid there are fees.

We can note that PayMate success is greater in developing countries. In fact in Western Europe or in the U.S. consumers have already plenty means of payment, so it's more difficult to make them adopting a new one. Nevertheless in fast developing countries cash payments are still very popular with all the risks associated. The mobile payments are a very cost effective solution to pay as if you have cash, limiting the risk of being attacked and stolen.

To conclude on the PayMate case, the main fact is that banks are entering the E-payment market. They do not consider it as marginal, and the success of PayPal has modified the way they try to compete. At the end of the 1990s, E-payment solutions provided by banks where very costly and bad designed for consumers. Now some banks' solutions can support a comparison with PayPal's one. 


\subsubsection{The Evolution of Paypal Strategy}

Originally designed for E-payment on the Internet, PayPal is one of the most successful companies of the new economy. With more than 230 millions of accounts worldwide, PayPal not only creates some new effective means of payments, it also survived to several attempts to compete with its services. Traditional banks proposals have not meet the success yet, Amazon attempt to propose its own payment system was a failure, and for the moment consumers seem to give their preference to PayPal. The PayPal Company is well known and we are not going to describe all the services provided. We are going to focus on some cutting edge strategy to illustrate our analysis of convergence on E-payment markets.

If PayPal appears to be less innovative on mobile payments, the company starts to compete against banks more directly than before. PayPal now offers debit and credit cards (VISA) at a very competitive price. For doing it, the PayPal bank has passed several agreements with other banks that have big ATM networks to allow the PayPal credit card holder to obtain cash from ATM with no fee. PayPal is now offering most of the services of an online bank, even some credit facilities associated with the credit card. The specificity of PayPal is vanishing and one of the main actors of E-payment market is now trying to compete with other banks.

\section{Conclusions: Competition and Cooperation}

This review of E-payment market shows an evolution of firms' strategies. First this market is no more marginal and E-payment originally designed for E-trade is now competing with traditional payments even in traditional retail stores. Bank money, with all the innovations such as deposits, bank transfers, checks or clearinghouses, has drastically reduced the use of cash in payments. The mobile phone payment may increase this trend of a virtualization of payments. It is somewhere ironic to see Internet firms' proposal of gold payment virtualization. Even in the most conservative view of money associated to a commodity, E-payments actors offer dematerialization.

The development of E-payment is also a real subject of interest in developing countries and traditional actors could not ignore it because they are at risk on being discarded by innovation. Traditional actors are now acting in networks with other groups of interest because they have no real mean to sell their own brand alone. PayMate is a competitive system designed against PayPal but it also a complex system of cooperation among members. PayPal moves toward a bank services is also a mix between competition and cooperation. PayPal is associated with BNP Paribas to offer a free access to ATM for its clients. The frontier between competition and cooperation is very thin in this case. The E-payment market has known disruptive innovations and firms with breaking strategies from the traditional payment market. The evolution of Internet firms and traditional banking firms combine to the needs of others key actors (mobile phone companies and internet services provider) has lead to some cooperation and convergence. Nevertheless, the existence of systems such as E-gold shows that E-payment entrepreneurs have not renounced yet to breaking strategies.

\section{References}

Bounie, D., \& Gazé, P. (2005). Payment and the Internet: Issues and Research Perspectives in Economics of Banking. In E. Brousseau \& N. Curien (Eds.), Internet and Digital Economics. Cambridge, England: Cambridge University Press.

Davies, G. (2002). History of Money. Cardiff, Great Britain: University of Wales Press.

Hayek, F. A. (1975). Choice in Currency: a Way to Stop Inflation. London, England: IEA.

Hayek, F. A. (1978). Denationalisation of Money. London, England: IEA.

Janson, N. (2004). The Development of Electronic Money: Toward the Privatisation of Money Issue. Journal of Internet Banking and Commerce, July.

Menger, C. (1892). On The Origins of Money. Economic Journal, 2, 239-55. http://dx.doi.org/10.2307/2956146

Menger, C. (1981). Principles of Economics. New York, NY: New York University Press.

Mises, L. (1981). The Theory of Money and Credit. Indianapolis, IN: Liberty Classics.

Say, J. B. (1841). Traité d'économie politique. Paris, France : Guillaumin.

Notes

Note 1. http://www.insee.fr/fr/indicateurs/indic_cons/pouvoir achat.pdf. Same results exist for the U.S.: one 1914 dollar is equivalent to 100 dollars in 2000 . The $20^{\text {th }}$ century is an inflation century. The current norm considers that price stability is an annual pace of $2 \%$ inflation. This pace is just two times higher than 
the increase of prices during «The Great Inflation» of the $16^{\text {th }}$ century when Spanish gold flowed over Europe. By historical standards, the $20^{\text {th }}$ century has accustomed people to high inflation.

Note 2. Historical data on exchange rates can be found on the Federal Reserve website. The series H10 is specific to exchange rates.

Note 3. Central banks use to keep a very large part of worldwide gold reserves and some countries have created taxes on gold transactions that discouraged gold payments. France used to have an $8 \%$ taxes specific on gold transaction, to buy something with gold you have to pay $8 \%$ more each time gold is used in transaction.

Note 4. It's the terms of the debate between Currency and Banking Schools during the $19^{\text {th }}$ century in Great Britain.

Note 5. http://www.paymate.co.in/

Note 6. http://www.e-gold.com/

Note 7. http://www.federalreserve.gov/releases/h10/Update/

Note 8. http://www.insee.fr/fr/indicateurs/indic_cons/pouvoir_achat.pdf

Note 9. http://www.paypal.fr/fr 